\title{
Tree species occurring on ariparian slope and correlations with soil variables in the upper Grande River, Minas Gerais, Brazil
}

\author{
Espécies arbóreas ocorrentes em uma mata ciliar de encosta com variáveis do solo no alto \\ Rio Grande, Minas Gerais
}

\author{
Israel Marinho Pereira $^{I^{*}}$ Soraya Alvarenga Botelho ${ }^{\mathrm{II}}$ Evandro Luiz Mendonça Machado ${ }^{\mathrm{I}}$ \\ Carlos Jose Andrade Silveira ${ }^{\text {III }}$
}

\begin{abstract}
Historically, forest landscapes have been modified by human activities, causing its destruction and fragmentation to exploit its resources. However, forests play a vital role in protecting the environment, especially on slops, hilltops, lakes, springs and river banks. This study aimed to understand the diversity and structure of vegetation on a slope of riparian forest in Bocaina de Minas, MG and identify key environmental variables that influence the spatial distribution of individual trees. An inventory of the tree community was conducted, in which ten of $10 \mathrm{~m} \times 40 \mathrm{~m}$ plots were allocated and systematically distributed throughout the study area. All individuals existing shrubs and trees within the plots with $1.30 \mathrm{~m}$ diameter $\geq 5.0 \mathrm{~cm}$ of soil were sampled in order to generate information on the horizontal structure, richness and diversity of the community. Variables related to the substrata were obtained for each plot from the topography and laboratory analysis of soil samples ( $\mathrm{pH}$, levels of $P, \mathrm{~K}, \mathrm{Ca}, \mathrm{Mg}$ and $\mathrm{Al}$, base saturation $(\mathrm{V})$, organic matter and levels of sand, silt and clay). Other variables such as distance from the river and successional stage of the plots, were also evaluated. In order to correlate environmental variables with the abundance distribution of the species, a canonical correspondence analysis (CCA) and Spearman correlation were used. The Shannon diversity index $\left(H^{\prime}\right)$ and evenness index $\left(J^{\prime}\right)$ obtained were 3.53 and 0.76 , respectively. The emerging patterns of environmental variables and the abundance of species indicate that these were distributed throughout the fragment, mainly due to the $P$ content in soil and successional stage of the plots. In addition, several species have produced significant correlations between their abundance in the plots and the variables related to successional stage, variations in soil, and distance from the banks of water courses.
\end{abstract}

Key words: riparian forest, species-environment relationship and multivariate analysis.

\section{RESUMO}

\begin{abstract}
Historicamente, as paisagens florestais têm sido modificadas pela ação do homem, causando sua destruição $e$ fragmentação ao explorar seus recursos. No entanto, as florestas têm papel fundamental de proteção ao meio ambiente, principalmente em encostas, topos de morros, lagos, nascentes $e$ às margens de rios. O presente trabalho teve como objetivo conhecer a diversidade e a estrutura da vegetação de uma mata ciliar de encosta em Bocaina de Minas $(M G)$ e identificar as principais variáveis ambientais que influenciam na distribuição espacial das espécies. Realizou-se um inventário da comunidade arbórea no período de 5 a 20 de junho de 2004, onde foram alocadas dez parcelas de $10 \mathrm{~m} \times 40 \mathrm{~m}$, distribuídas sistematicamente por todo o fragmento. Todos os indivíduos arbustivo-arbóreos existentes no interior das parcelas com diâmetro a $1,30 \mathrm{~m}$ do solo $\geq 5,0 \mathrm{~cm}$ foram amostrados. Variáveis relacionadas ao substrato $(\mathrm{pH}$, teores de $P, K, C a, M g$ e $\mathrm{Al}, \mathrm{V}, \mathrm{MO}$, areia, silte e argila) foram obtidas para cada parcela a partir de análises laboratoriais de amostras do solo. Outras variáveis como distância do rio e estágio sucessional também foram avaliadas. Para correlacionar as variáveis ambientais com a distribuição da abundância das espécies, foram utilizadas técnicas de análise de correspondência canônica (CCA) e correlação de Spearman. Os valores para os índices de diversidade de Shannon $\left(H^{\prime}\right) e$ equabilidade de Pielou ( $\left.J^{\prime}\right)$ obtidos foram 3,53 e 0,76. Os padrões emergentes das variáveis ambientais e a abundância das espécies indicam que estas se distribuíram ao longo do fragmento, principalmente em função do teor de $P$ no solo $e$ do estágio sucessional das parcelas. Além disso, várias espécies produziram correlações significativas entre sua abundância nas parcelas e as variáveis referentes ao estágio sucessional, variações edáficas químicas, texturais e distância até as margens dos cursos d'água.
\end{abstract}

Palavras-chave: mata ciliar, relação espécie-ambiente $e$ análise multivariada.

IDepartamento de Engenharia Florestal, Universidade Federal dos Vales do Jequitinhonha e Mucuri (UFVJM), Campus JK,

Rodovia MGT, 367, Km 583, 5000, Alto Jacuba, 39100-000, Diamantina, MG, Brasil. E-mail: imarinhopereira@gmail.com.

*Autor para correspondência.

"Departamento de Engenharia Florestal, Universidade Federal de Lavras (UFLA), Lavras, MG, Brasil.

"'Programa de Pós-graduação em Ciência Florestal, UFVJM, Diamantina, MG, Brasil. 
Tree species occurring on ariparian slope and correlations with soil variables in the upper Grande River, Minas Gerais, Brazil. 2193

\section{INTRODUCTION}

Human settlement in Brazil has historically been along the banks of water courses. A consequence of such settlement has been the large-scale destruction of riparian forests, owing first to the demands for timber and, later, those of agriculture. However, the riparian vegetation plays a valuable role in protecting rivers against silting from various types of erosion, serves as a habitat for numerous terrestrial and aquatic species, provides the gene flow between populations (CARVALHO et al., 2000; PEREIRA et al., 2010), and absorbs carbon monoxide, providing $\mathrm{s}$ both regional and global benefits (HIGUSHI \& VELASCO, 2009).

According to DAVIDE et al. (1996), a key aspect in the riparian reforestation of reservoirs is the choice of appropriate species. One must consider that riparian forests comprise different environments, ranging from mesic sites, with no effect of flooding, to areas of depletion, where plants are partially or completely submerged during periods of flood.

It is know that the factors which most influence the spatial distribution of plant populations in tropical forests, both at the regional and local levels, are the nutritional quality of the soil, topography, humidity and light intensity(MACHADO et al., 2008). Topographic and soil variables, such as chemical and physical properties, are temporally more constant than light, although they can have a very pronounced spatial variation. In riparian forests, soil properties (physical, chemical and moisture levels) usually vary with the distance from the river, due to topographic gradient and the dynamics of flooding (VAN DEN BERG \& SANTOS, 2003).

Considering the aforementioned questions about riparian forests, as well as the importance of environmental variables in the spatial distribution of individual trees, the present study aimed to verify which are the main environmental variables of a riparian slope that influence the distribution of species in a region of the upper Rio Grande River in Bocaina de Minas, MG.

\section{METHODOLOGY}

Study area - the study was carried out in a riparian forest area in the municipality of Bocaina de Minas, Minas Gerais state, and characterized as follows: remnant (approx. 15 hectares) of riparian forest on a slope, in intermediate successional stage, at the margins of the Rio Grande River (22 ${ }^{\circ} 14^{\prime}$ S and $44^{\circ} 34^{\prime}$ W) at an altitude of $1500-1580 \mathrm{~m}$. The region's climate is Cfa (moist subtropical, following Köppen's classification), with yearly temperature of $16.7^{\circ} \mathrm{C}$ and yearly average rainfall of $2108 \mathrm{~mm}$. The predominant soil types (FAO, 1990) are Fluvisols common on the lower slope, with lower drainage and Ferralsols, common on the medium slope, with good marked drainage (CARVALHO et al., 2005).

Inventory of the arboreal stratum - the inventory of the arboreal stratum was done in a total sampling area of 0.4 hectare divided into ten plots of $10 \mathrm{~m}^{\prime} 40 \mathrm{~m}$. The plots were set up according to the altitude gradient, with plots placed on the lower slope close to the river, on the middle slope and on the high slope (top). A compass was used for the alignment of the plots and a measuring tape for the measurement of the horizontal distances. Every living arboreal individual within the plots with a trunk circumference at breast height $(\mathrm{CBH})$ of $15.7 \mathrm{~cm}$ or higher was recorded, identified and labeled with a numbered aluminum tag.

Inventory of the environmental variables The declivity was assessed with a Blume-Leiss hypsometer and the data used to construct maps with level curves equidistant $1 \mathrm{~m}$. Three topographic variables per plot were calculated from the plot corner coordinates: (1) vertical distance from the river (the difference between the average altimetric level of the four corners of the plot and the altimetric level of the river); (2) topographic unevenness (the difference between the maximum and minimum altimetric levels of the plot); and (3) average declivity (average of the declivity on the four sides of the plot).

The predominant soil types in each plot were classified according to the Brazilian System of Soil Classification (EMBRAPA, 1999), up to the level of subgroup (or $4^{\text {th }}$ categoric level) and including the textural grouping and classes of drainage. Samples of the surface soil (up to $20 \mathrm{~cm}$ in depth) were collected at the center of each plot. Chemical and textural analyses were carried out at the UFLA's Laboratory of Soil Analysis, following the protocol of EMBRAPA (1997), including pH, levels of $\mathrm{P}, \mathrm{K}, \mathrm{Ca}, \mathrm{Mg}$ and $\mathrm{Al}$, base saturation $(\mathrm{V})$, organic matter and levels of sand, silt and clay.

Physiognomic structure and diversity - the following classical phytosociological parameters were calculated, as proposed by MUELLER-DOMBOIS \& ELLEMBERG (1974): absolute density, absolute frequency and absolute dominance expressed by the basal area per hectare.

Statistical analyses of the physiognomic and environmental variables - a canonical correspondence analysis (CCA) (TER BRAAK, 1987) was performed to analyze the correlations between the environmental and vegetational gradients, using the software PC-ORD for Windows 4.14, (MCCUNE \& MEFFORD, 1999). The abundance matrix of the species 
was composed of the number of individuals per plot of each species with five or more individuals in the total sample of each area. According to the recommendations of TER BRAAK (1995), the abundance values were transformed by $\log _{10}(a+1)$ to compensate for the deviation caused by a few very high values.

The environmental variables matrix included, in principle, all the chemical and textural variables of the soil, the drainage class and the three topographic variables. The drainage classes were expressed as an ordinal variable, by attributing grades to the categories as described by EMBRAPA (1999): 4 - moderately drained, 5 - well drained, and 6 - highly drained (other drainage classes were not found). Another variable assessed was the successional stage "rank suc". To verify the correlation of the species distribution with the different successional stages, an assessment was done in each plot in relation to its successional stage. The classification of the successional stages was based on OLDEMAN (1990) and ROCHA et al. (2005), in which grades were attributed for every successional stage, with the lowest grade (1) referring to the initial successional stages and the higher ones referring to the final, more complex stages. The successional stages and their respective grades were: plots with gaap and Pteridium ssp. and/or Gleichenia ssp. in more than $60 \%$ of the area (1); plots undergoing initial succession process, with Pteridium sp. and/or Gleichenia sp. in less than $60 \%$ of the area (2); plots in an intermediate succession process (3); plots in an advanced succession process (4) and plots typical of mature forest (5).

The initial matrix was composed of 18 environmental variables. After doing a preliminary CCA, with all variables, those which were poorly correlated or highly redundant were eliminated. The variables which were most representative and which showed the strongest correlation with the ordination axes were: vertical distance from the river, successional stage, level of aluminum ( $\mathrm{Al})$, amount of sand and level of phosphorus $(\mathrm{P})$. The Spearman correlation coefficient was also calculated for each plot (ZAR, 1998) between the species abundance and the distance from the river (VD), phosphorus level (P), aluminum (Al), sand, vertical distance and successional stage (SS).

\section{RESULTS AND DISCUSSION}

Physiognomic structure, diversity and floristic similarity - it was sampled a total of 872 individuals, 98 species, 61 genera and 35 families (Table 1). The number of species found in this research can be considered intermediary when compared to other surveys carried out in forests that protect springs in the upper Rio Grande River region (VAN DEN BERG \& OLIVEIRA-
FILHO, 2000; OLIVEIRA-FILHO et al., 2004a; DALANESI et al., 2004) and in other remnants of riparian forests located along the rivers in the same region (BOTREL et al., 2002; SOUZA et al., 2003).

The five species with the highest number of individuals totalized $43.2 \%$ of the total sample, those being Myrsine umbellata (13.6\%), Croton organensis (9.3\%), Tibouchina arborea (8.1\%), Miconia sellowiana (6.4\%) and Psychotria vellosiana (5.8\%).

The values of tree density (2180 trees hectare $^{-1}$ ) of the area under study are among the higher ones recorded in 20 surveys carried out in the region of the upper Rio Grande (969 trees.hectare ${ }^{-1}$, PEREIRA et al., 2007, to 2683 trees ha-1 ${ }^{-1}$ BOTREL et al., 2002). The values of basal area $\left(16.73 \mathrm{~m}^{2} \mathrm{ha}^{-1}\right)$ were also high when compared to other areas, which ranged from $19.79 \mathrm{~m}^{2}$ ha $^{-1}$ to $34.16 \mathrm{~m}^{2}$ ha $^{-1}$ (PEREIRA et al., 2007). These values indicate a relatively density and biomass in relation to the majority of the values reported for the forests of the region of High Rio Grande river. According to OLIVEIRA-FILHO et al. (2004b), the differences among those forests are related to the historic disturbance, border effect, nutrients pool and water regime in the soil.

The Shannon diversity index (H') and the Pielou index (J') were 3.53 and 0.76 , respectively. The Shannon diversity index (3.53) showed the closest value to those reported around thesprings (which varied from 3.90 to 4.20 . The Pielou equality index found in the present study is close to that reported for the forests around springs in the studies mentioned above $(0.75$ to 0.88 ) and along the rivers ( 0.76 to 0.86 ). Lower values of equality found in the area indicate that there is a higher concentration of abundance in a lower number of species, which characters the existence of strong ecological dominance common in tropical forests (RICHARDS, 1952). In this regard, the most notable species in the area were Myrsine umbellata, Croton organensis, Tibouchina arborea, Miconia sellowiana and Psychotria vellosiana.

Species distribution - the results of the canonical correspondence analysis (CCA) are represented in the ordination diagrams (Figure 1). The eigenvalues of the CCA for the two first ordination axes were 0.45 for the axis 1 and 0.32 for axis 2 . The two first and second axes explained $29.5 \%$ and $20.5 \%$, respectively, of the overall variance of the data, with an accumulated total of 50\%. Furthermore, the Monte Carlo permutation test indicated that the abundance of species and the environmental parameters correlated significantly with the first ordination axis $(\mathrm{P}<0.05)$. In the CCA diagrams, the plots and the species are represented by points that correspond to the 
Table 1 - Arboreal species inventoried in three riparian forests in the municipally of Bocaina de Minas, Minas Gerais state, in alphabetical order of species, followed by their quantitative values obtained from the sample of 46 plots of $400 \mathrm{~m}^{2} . \mathrm{Ni}=$ number of individuals; $\mathrm{NP}=$ number of plots with the species; $\mathrm{Ab}=$ basal area $\left(\mathrm{m}^{2}\right)$ and $\mathrm{VI}=$ importance value $(\%)$.

\begin{tabular}{|c|c|c|c|c|c|c|c|c|c|}
\hline Espécie & $\mathrm{Ni}$ & NP & DA Ind ha ${ }^{-1}$ & DR $\%$ & FA $\%$ & FR \% & $\mathrm{DoAm}^{2} \mathrm{ha}^{-1}$ & DoR \% & VI $\%$ \\
\hline Myrsine umbellata & 126 & 9 & 315 & 14.5 & 90 & 4 & 2.1816 & 13 & 10.5 \\
\hline Tibouchina arborea & 71 & 8 & 178 & 8.14 & 80 & 3.6 & 1.9662 & 11.8 & 7.82 \\
\hline Croton organensis & 81 & 6 & 203 & 9.29 & 60 & 2.7 & 1.7732 & 10.6 & 7.52 \\
\hline Miconia sellowiana & 56 & 8 & 140 & 6.42 & 80 & 3.6 & 0.706 & 4.22 & 4.73 \\
\hline Psychotria vellosiana & 51 & 9 & 128 & 5.85 & 90 & 4 & 0.6328 & 3.78 & 4.54 \\
\hline Miconia theaezans & 39 & 6 & 97.5 & 4.47 & 60 & 2.7 & 0.7844 & 4.69 & 3.94 \\
\hline Clethra scabra & 40 & 7 & 100 & 4.59 & 70 & 3.1 & 0.5842 & 3.49 & 3.73 \\
\hline Piptocarpha regnellii & 41 & 6 & 103 & 4.7 & 60 & 2.7 & 0.6314 & 3.77 & 3.71 \\
\hline Prunus myrtifolia & 18 & 5 & 45 & 2.06 & 50 & 2.2 & 0.7435 & 4.45 & 2.91 \\
\hline Alchornea triplinervia & 22 & 7 & 55 & 2.52 & 70 & 3.1 & 0.4015 & 2.4 & 2.68 \\
\hline Myrsine gardneriana & 22 & 6 & 55 & 2.52 & 60 & 2.7 & 0.3797 & 2.27 & 2.49 \\
\hline Eremanthus erythropappus & 24 & 3 & 60 & 2.75 & 30 & 1.3 & 0.3436 & 2.05 & 2.05 \\
\hline Guapira opposita & 16 & 6 & 40 & 1.83 & 60 & 2.7 & 0.2637 & 1.58 & 2.03 \\
\hline Guatteria australis & 20 & 3 & 50 & 2.29 & 30 & 1.3 & 0.4013 & 2.4 & 2.01 \\
\hline Mimosa scabrela & 7 & 2 & 17.5 & 0.8 & 20 & 0.9 & 0.5675 & 3.39 & 1.69 \\
\hline Vernonanthura discolor & 13 & 2 & 32.5 & 1.49 & 20 & 0.9 & 0.3864 & 2.31 & 1.56 \\
\hline Myrsine coriacea & 16 & 4 & 40 & 1.83 & 40 & 1.8 & 0.1427 & 0.85 & 1.49 \\
\hline Miconia cinnamomifolia & 16 & 3 & 40 & 1,83 & 30 & 1,3 & 0,1875 & 1,12 & 1,43 \\
\hline Vernonanthura divaricata & 8 & 3 & 20 & 0,92 & 30 & 1,3 & 0,2015 & 1,2 & 1,15 \\
\hline Nectandra grandiflora & 6 & 4 & 15 & 0,69 & 40 & 1,8 & 0,1394 & 0,83 & 1,1 \\
\hline Myrcia splendens & 9 & 4 & 22,5 & 1,03 & 40 & 1,8 & 0,0697 & 0,42 & 1,08 \\
\hline Sapium glandulosum & 6 & 3 & 15 & 0,69 & 30 & 1,3 & 0,1995 & 1,19 & 1,07 \\
\hline Cyathea corcovadensis & 4 & 3 & 10 & 0,46 & 30 & 1,3 & 0,2361 & 1,41 & 1,07 \\
\hline Cyathea phalerata & 6 & 3 & 15 & 0.69 & 30 & 1.3 & 0.1788 & 1.07 & 1.03 \\
\hline 25 species with $\mathrm{VI}>1.0 \%$ & 718 & & 1795 & 82.3 & 1200 & 53 & 14.10 & 84.3 & 73.3 \\
\hline 74 species with VI $<1.0 \%$ & 154 & & 385 & 17.5 & 1050 & 46 & 2.63 & 15.7 & 26.7 \\
\hline Total & 872 & & 2180 & 100 & 2250 & 100 & 16.73 & 100 & 100 \\
\hline
\end{tabular}

approximated optimal distribution in the bidimensional space defined by the ordination.

The ordination of the plots in the first axis (Figure 1) clearly suggests a strong separation between the plots on Fluvisols, clustered in the upper part of the axis 2, from the plots of Ferralsols, clustered in relation to the altitudinal gradient and successional stage. The environmental gradient, from left to right, involves the decrease of phosphorus content $(\mathrm{P})$, decrease of sand content, increase in the distance from the river and the increase of aluminum content $(\mathrm{Al})$. In relation to the species ordination of the CCA (Figure 1B), three distinct groups appeared. The first one is composed of species such as Cyathea phalerata, Mimosa scabrela, Myrsine gardeneriana, Sapium glandulosum, Solanum lepidotum, Cyathea delgadii, Croton organensis and Miconia theaezans. These species were present exclusively or in greater abundance in the plots on Fluvisols, closer to the river and with the highest phosphorus and sand content. This was also verified by the Spearman correlation, in which several species from this group showed high correlations to some of these variables (Table 2). In general, the correlation between environmental variables and species was clear, mainly for those related to soil moisture and drainage and successional stages in the plots. The influence of soil moisture on the distribution of tree species and on the formation of physiognomies in tropical forests has been emphasize by various authors (BASTNET, 1992; METZGER et al., 1997; CLARK et al., 1998).

The second group was composed of species such as Clethra scabra, Tibouchina pulchra, Miconia sellowiana, Myrsine coriacea, Piptocarpha regnellii, Eremanthus erythropappus and Miconia cinnamomifolia, which were more abundant in the plots at highest altitudes, more distant from the river and with the highest aluminum content, suggesting that 


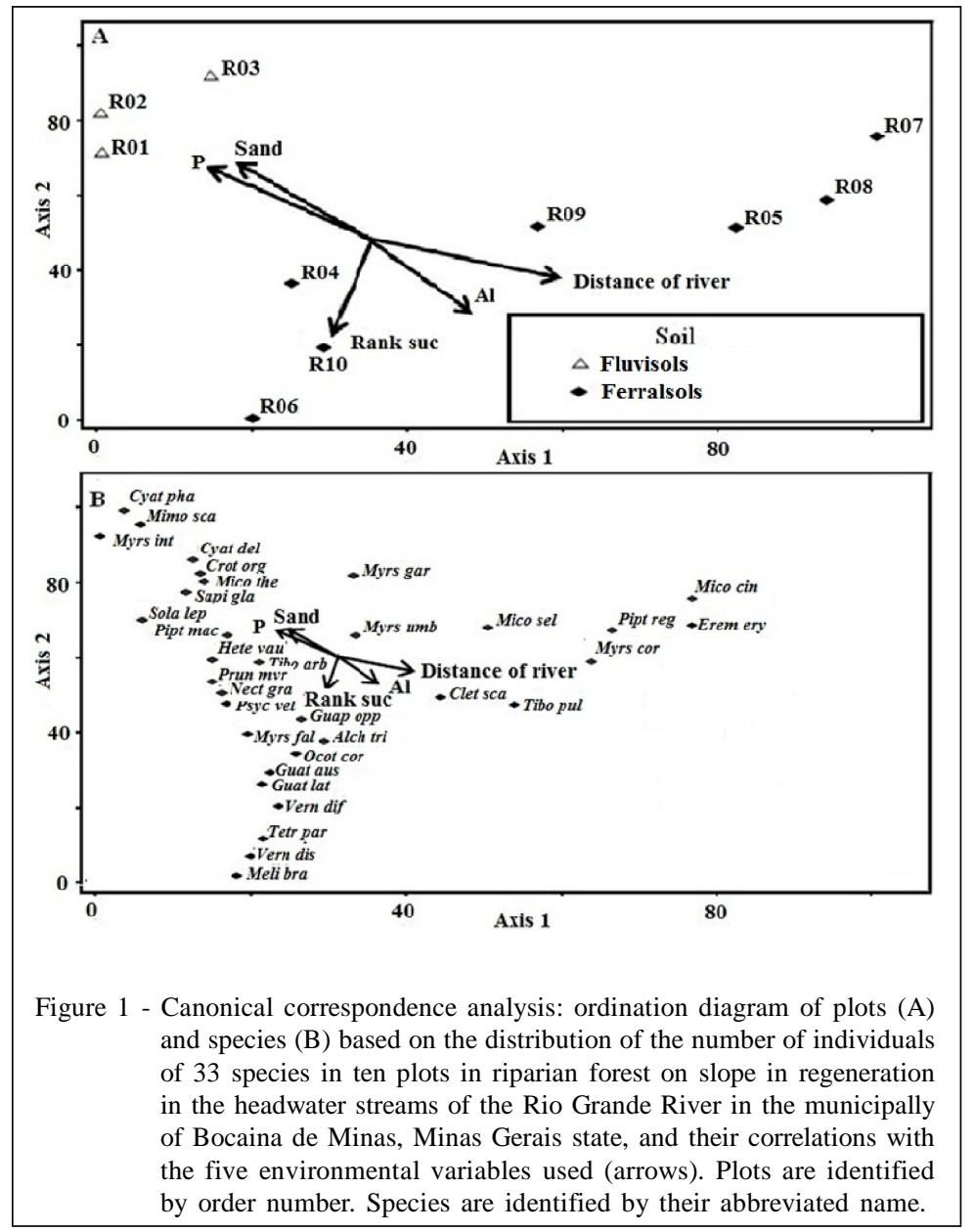

they are typical of typical of well-drained mesic sites. The third group was composed of plots with less human interference, especially those with a lower occurrence of Pteridium ssp. e Gleichenia ssp. In this group, the following species were most abundant: Alchornea triplinervia, Guapira opposita, Guatteria latifolia, Meliosma brasiliensis, Myrcia splendens, Nectandra grandiflora, Ocotea corymbosa, Psychotria vellosiana, Prunus myrtifolia, Tibouchina arborea, Trembleya parviflora, Vernonanthura diffusa and Vernonanthura discolor.

According to BRINSON (1990), the spatial distribution of plant species in riparian environments is strongly affected by geomorphological aspects, since they are normally associated with differences in the water regime in the soil or with flooding. The relief of the river bank represents one of the main factors that affect the floristic composition of riparian areas, since it exposes the vegetation, at high or low levels, to variation in the level of groundwater and to floods, determining which plant species are able to grow in these areas (RODRIGUES, 1989).

\section{CONCLUSION}

The results obtained in this study allowed to conclude that the composition, structure and diversity of the arboreal stratum in the riparian forest along the headwater streams of the Rio Grande differed not only as a function of the environment, but also as a consequence of their stages of maturity. These differences were more evident in relation to the composition of species between the different environment (Neosols Fluvico and Red-Yellon Latossols).

The distribution of species in the different habitats of riparian forest was significantly correlated to the water regime of the soils (distance from the river and drainage), demonstrating the existence of gradients of topographic elevations, moisture and seral stage. 
Tree species occurring on ariparian slope and correlations with soil variables in the upper Grande River, Minas Gerais, Brazil. 2197

Table 2 - Spearman correlation coefficients and their significance $(p)$ among the abundance of 33 arboreal species used in the CCA and the variables phosphorus level (P), aluminum (Al), sand, vertical distance (VD) and successional stage (SS), in a riparian forest on a slope in regeneration in the Bocaina de Minas, Minas Gerais state $* P<0.05 ; * * P<0.01 ; * * * P<0.001$; ns $=$ not significant.

\begin{tabular}{|c|c|c|c|c|c|c|c|c|c|c|c|}
\hline Species & Code & $P$ & $p$ & Al & $p$ & Sand & $p$ & VD & $p$ & SS & $P$ \\
\hline Alchornea triplinervia & Alch tri & -0.290 & ns & 0.514 & ns & -0.342 & ns & 0.023 & $\mathrm{~ns}$ & 0.825 & $* *$ \\
\hline Clethra scabra & Clet sca & -0.548 & $\mathrm{~ns}$ & 0.204 & ns & -0.635 & $*$ & 0.560 & $\mathrm{~ns}$ & 0.627 & $*$ \\
\hline Croton organensis & Crot org & 0.973 & $* * *$ & -0.729 & $* *$ & 0.905 & $* * *$ & -0.876 & $* * *$ & -0.458 & ns \\
\hline Cyathea delgadii & Cyat del & 0.470 & $\mathrm{~ns}$ & -0.709 & $*$ & 0.536 & $\mathrm{~ns}$ & -0.498 & $\mathrm{~ns}$ & -0.269 & ns \\
\hline Cyathea phalerata & Cyat pha & 0.600 & $*$ & -0.814 & $* *$ & 0.692 & $*$ & -0.671 & $*$ & -0.467 & ns \\
\hline Eremanthus erythropappus & Erem ery & -0.302 & $\mathrm{~ns}$ & 0.228 & ns & -0.206 & $\mathrm{~ns}$ & 0.313 & $\mathrm{~ns}$ & -0.239 & ns \\
\hline Guapira opposita & Guap opp & -0.165 & $\mathrm{~ns}$ & 0.359 & ns & -0.120 & $\mathrm{~ns}$ & -0.143 & ns & 0.707 & $*$ \\
\hline Guatteria australis & Guat aus & -0.037 & $\mathrm{~ns}$ & 0.099 & ns & -0.181 & ns & -0.114 & $\mathrm{~ns}$ & 0.360 & ns \\
\hline Guatteria latifolia & Guat lat & -0.092 & $\mathrm{~ns}$ & 0.259 & ns & -0.158 & $\mathrm{~ns}$ & -0.151 & $\mathrm{~ns}$ & 0.481 & $\mathrm{~ns}$ \\
\hline Heterocondylus vauthierianus & Hete vau & 0.188 & $\mathrm{~ns}$ & -0.122 & ns & 0.010 & $\mathrm{~ns}$ & -0.239 & $\mathrm{~ns}$ & 0.137 & ns \\
\hline Meliosma brasiliensis & Meli bra & -0.205 & $\mathrm{~ns}$ & 0.511 & ns & -0.073 & ns & -0.103 & ns & 0.566 & ns \\
\hline Miconia cinnamomifolia & Mico cin & -0.439 & $\mathrm{~ns}$ & 0.384 & ns & -0.243 & ns & 0.572 & $*$ & -0.253 & ns \\
\hline Miconia sellowiana & Mico sel & -0.164 & $\mathrm{~ns}$ & 0.068 & ns & -0.307 & $\mathrm{~ns}$ & 0.141 & $\mathrm{~ns}$ & -0.085 & ns \\
\hline Miconia theaezans & Mico the & 0.879 & $* * *$ & -0.435 & $\mathrm{~ns}$ & 0.735 & $* *$ & -0.711 & $*$ & -0.355 & $\mathrm{~ns}$ \\
\hline Mimosa scabrela & Mimo sca & 0.709 & $*$ & -0.315 & $\mathrm{~ns}$ & 0.616 & $*$ & -0.577 & $\mathrm{~ns}$ & -0.226 & ns \\
\hline Myrcia splendens & Myrc spl & -0.060 & $\mathrm{~ns}$ & -0.014 & ns & -0.274 & $\mathrm{~ns}$ & -0.111 & $\mathrm{~ns}$ & 0.554 & ns \\
\hline Myrsine coriacea & Myrs cor & -0.313 & $\mathrm{~ns}$ & 0.032 & ns & -0.359 & $\mathrm{~ns}$ & 0.247 & $\mathrm{~ns}$ & -0.203 & $\mathrm{~ns}$ \\
\hline Myrsine gardneriana & Myrs gar & 0.695 & $*$ & -0.198 & ns & 0.660 & $*$ & -0.455 & $\mathrm{~ns}$ & -0.341 & $\mathrm{~ns}$ \\
\hline Myrsine intermedia & Myrs int & 0.609 & $*$ & -0.640 & $*$ & 0.644 & $*$ & -0.647 & $*$ & -0.303 & ns \\
\hline Myrsine umbellata & Myrs umb & 0.021 & $\mathrm{~ns}$ & -0.492 & ns & -0.120 & $\mathrm{~ns}$ & -0.046 & $\mathrm{~ns}$ & 0.018 & $\mathrm{~ns}$ \\
\hline Nectandra grandiflora & Nect gra & 0.096 & $\mathrm{~ns}$ & 0.152 & ns & -0.153 & $\mathrm{~ns}$ & -0.071 & $\mathrm{~ns}$ & 0.594 & $*$ \\
\hline Ocotea corymbosa & Ocot cor & -0.197 & $\mathrm{~ns}$ & 0.127 & ns & -0.482 & $\mathrm{~ns}$ & 0.222 & $\mathrm{~ns}$ & 0.606 & $*$ \\
\hline Piptocarpha macropoda & Pipt mac & 0.111 & $\mathrm{~ns}$ & -0.166 & ns & -0.118 & $\mathrm{~ns}$ & -0.048 & $\mathrm{~ns}$ & 0.321 & $\mathrm{~ns}$ \\
\hline Piptocarpha regnellii & Pipt reg & -0.479 & $\mathrm{~ns}$ & 0.471 & ns & -0.290 & ns & 0.663 & $*$ & -0.295 & ns \\
\hline Prunus myrtifolia & Prun myr & 0.109 & $\mathrm{~ns}$ & -0.156 & ns & -0.024 & $\mathrm{~ns}$ & -0.268 & $\mathrm{~ns}$ & 0.225 & $\mathrm{~ns}$ \\
\hline Psychotria vellosiana & Psyc vel & -0.274 & $\mathrm{~ns}$ & 0.223 & ns & -0.517 & $\mathrm{~ns}$ & 0.215 & $\mathrm{~ns}$ & 0.751 & $* *$ \\
\hline Sapium glandulosum & Sapi gla & 0.628 & $*$ & -0.301 & ns & 0.454 & $\mathrm{~ns}$ & -0.562 & $*$ & -0.085 & $\mathrm{~ns}$ \\
\hline Solanum lepidotum & Sola lep & 0.269 & $\mathrm{~ns}$ & -0.568 & ns & 0.432 & ns & -0.480 & $\mathrm{~ns}$ & -0.213 & ns \\
\hline Tetrorchidium parvulum & Tetr par & -0.288 & $\mathrm{~ns}$ & 0.545 & ns & -0.280 & ns & 0.020 & $\mathrm{~ns}$ & 0.795 & $* *$ \\
\hline Tibouchina arborea & Tibo arb & 0.118 & $\mathrm{~ns}$ & -0.107 & ns & -0.129 & ns & -0.246 & $\mathrm{~ns}$ & 0.424 & ns \\
\hline Tibouchina pulchra & Tibo pul & -0.428 & $\mathrm{~ns}$ & 0.106 & ns & -0.422 & ns & 0.258 & $\mathrm{~ns}$ & 0.021 & $\mathrm{~ns}$ \\
\hline Vernonanthura diffusa & Vern dif & -0.237 & $\mathrm{~ns}$ & 0.220 & ns & -0.491 & ns & 0.217 & $\mathrm{~ns}$ & 0.697 & $*$ \\
\hline Vernonanthura discolor & Vern dis & -0.224 & $\mathrm{~ns}$ & 0.526 & ns & -0.111 & ns & -0.083 & ns & 0.616 & $*$ \\
\hline
\end{tabular}

\section{REFERENCES}

BOTREL, R.T. et al. Influência do solo e topografia sobre as variações da composição florística e estrutural da comunidade arbóreo-arbustiva de uma floresta estacional semidecidual em Ingaí, MG. Revista Brasileira de Botânica, São Paulo, v.25, n.2, p.195-213, 2002. Disponível em: <http://dx.doi.org/ 10.1590/S0100-84042010000200015>. Acesso em: 20 maio, 2009. doi:10.1590.

BRINSON, M.M.; REVEBRINSON, M.M. Reveine forests. In: LUGO, A.E. et al. (Eds.). Ecossystems of the world 15 : forested wetlands. Amsterdam: Elsevier, 1990. p.128-145.

CARVALHO, D.A. et al. Variações florísticas e estruturais do compartimento arbóreo de uma floresta ombrófila alto-montana às margens do Rio Grande, Bocaina de Minas, MG Brasil. Acta Botanica
Brasilica, São Paulo, v.19, n.1, p91-109, 2005. Disponível em: <http://dx.doi.org/10.1590/S0102-33062011000200020>. Acesso em: 22 jun. 2009. doi: 10.1590 .

CARVALHO, D.A. et al. Florística e estrutura da vegetação arbórea de um fragmento de floresta semidecidual ás margens do reservatório da usina hidrelétrica Dona em uma floresta de galeria em Itutinga, MG, Brasil. Acta Botanica Brasilica, Feira de Santana, v.14, n.1, p.37-55, 2000. Disponível em: <http://dx.doi.org/10.1590/S0102-33062011000200020〉. Acesso em: 20 jun. 2009. doi: 10.1590.

CLARK, D.B. et al. Edaphic variation and the mesoscale distribution of tree species in a neotropical rain forest. Journal of Ecology, v.86, n.1, p.101-112, 1998. Disponível em: <http:/ /onlinelibrary.wiley.com/doi/ $10.1046 / j .1365$ 2745.1998.00238>. Acesso em: 20 mar. 2009. doi: 10.1046/ j.1365-2745.1998.00238. 
DALANESI, P.E. et al. Flora e estrutura do componente arbóreo da floresta do Parque Ecológico Quedas do Rio Bonito, Lavras, MG, e correlações entre a distribuição das espécies e variáveis ambientais. Acta Botanica Brasilica, São Paulo, v.18, n.4, p.737-757, 2004. Disponível em: <http://dx.doi.org/10.1590/ S0102-33062011000200020>. Acesso em: 20 mar. 2009. doi: 10.1590 .

DAVIDE, A.C. et al. Comportamento de espécies florestais de mata ciliar em área de depleção do reservatório da Usina Hidrelétrica de Camargos - Itutinga, MG. Cerne, Lavras, v.2, n.1, p.20-40, 1996

EMBRAPA. Manual de métodos de análise de solo. 2.ed. Rio de Janeiro: Empresa Brasileira de Pesquisa Agropecuária, Centro Nacional de Pesquisa de Solos, 1997. 212p.

EMBRAPA. CENTRO NACIONAL DE PESQUISA DE SOLOS. Sistema brasileiro de classificação de solos. Brasília: EMBRAPA Produção de Informação, 1999. 412p.

FAO -UNESCO. Soil map of the world at scale 1:5.000.000. In: WORD CONGRESS OF SOIL SCIENCE, 14., 1990, Kyoto. Proceedings... Kyoto: International Soil Science Society, 1990. 190p.

RIZZARDI, M.A.; MILGIORANÇA, M.E. Avaliação de cultivares do ensaio nacional de girassol, Passo Fundo, RS, 1991/ 92. In: JORNADA DE PESQUISA DA UFSM, 1., 1992, Santa Maria, RS. Anais... Santa Maria: Pró-reitoria de Pós-graduação e Pesquisa, 1992. V.1. 420p. p.236.

MACHADO, E.L.M. et al. Efeitos do substrato, bordas e proximidade espacial na estrutura da comunidade arbórea de um fragmento florestal em Lavras, MG. Revista Brasileira Botânica, São Paulo, v.31, n.2, p.287-302, 2008. Disponível em: 〈http://dx.doi.org/10.1590/S0100-84042010000200015>. Acesso em: 25 maio, 2009. doi:10.1590.

METZGER, J.P. et al. Pattern of tree species diversity in riparian forest fragments of different widths (SE Brazil). Plant Ecology, Dordrecht, v.133, n.2, p135-152, 1997. Disponível em: 〈http://www.springerlink.com/content/1385-0237/213>. Acesso em: 05 maio, 2010. doi: 10.1023.

MUELlER-DOMBOIS, D.; ELLENBERG, H. Aims and methods of vegetation ecology. New York: John Wiley \& Sons, 1974. 547p.

OLDEMAN, R.A.A. Forest. Elements of silvology. Berlin: Springer-Verlag, 1990. 640p.

OLIVEIRA-FILHO, A.T. et al. Diversity and structure of the tree community of a fragment of tropical secondary Forest the Brazilian Atlantic Forest domain 15 and 40 yars after logging. Revista Brasileira Botânica, São Paulo, v.27, n.4, p.685701, 2004a. Disponível em: <http://dx.doi.org/10.1590/S010084042010000200015>. Acesso em: 17 mar. 2009. doi:10.1590.

OLIVEIRA-FILHO, A.T. et al. Variações estruturais do compartimento arbóreo de uma floresta semidecídua alto-montana na chapada das Perdizes, Carrancas, MG. Revista Brasileira Botânica, São Paulo, v.27, n.2, p291-309, 2004b. Disponível em: 〈http://dx.doi.org/10.1590/S0100-84042010000200015>. Acesso em: 20 maio, 2009. doi:10.1590.
PEREIRA, I.M. et al. Caracterização ecológica de espécies arbóreas ocorrentes em ambientes de mata ciliar, como subsídio à recomposição de áreas alteradas nas cabeceiras do Rio Grande, Minas Gerais, Brasil. Ciência Florestal, Santa Maria, v.20, n.2, p.235-253, 2010.

PEREIRA, J.A.A. et al. Environmental heterogeneity and disturbance by humans control much of the tree species diversity of Atlantic montane forest fragments in SE Brazil. Biodiversity and Conservation, New York, v.16, n.6, p.1761-1784, 2007. Disponível em: 〈http://www.springerlink.com/content/100125>. Acesso em: 07 maio, 2010. doi: 10.1007/s10531-006-9002-4.

RICHARDS, P.W. The tropical rain forest. 2.ed. Cambridge: Cambridge University, 1952. 600p.

ROCHA, C.T.V. et al. Comunidade arbórea de um continuum entre floresta paludosa e de encosta em Coqueiral, Minas Gerais, Brasil. Revista Brasileira Botânica, São Paulo, v.28, n.2, p.203-218, 2005. Disponível em: <http://dx.doi.org/10.1590/ S0100-84042010000200015>. Acesso em: 20 maio, 2009. doi: 10.1590 .

RODRIGUES, R.R. Análise das formações ripárias. In: SIMPÓSIO SOBRE MATAS CILIAR, 1989, Campinas, SP. Anais... Campinas, SP: Fundação Cargil, 1989. p.171-191.

SOUZA, J.S. et al. Análise das variações florísticas e estruturais da comunidade arbórea de um fragmento de floresta semidecídua às margens do rio Capivari, Lavras-MG. Revista Árvore, Viçosa, v.27, n.2, p.185-206, 2003. Disponível em: <http://dx.doi.org/ 10.1590/S0100-67622006000200013>. Acesso em: 10 maio, 2009. doi: 10.1590 .

TER BRAAK, C.J.F. Ordination. In: JONGMANET, R.H.G. al. (eds.). Data analysis in community and landscape ecology. Cambridge: Cambridge University, 1995. p.91-173.

TER BRAAK, C.J.F. The analysis of vegetation-environment relationships by canonical correspondence analysis. Vegetatio, Dordrecht, v.69, n.1, p.69-77, 1987. Disponível em: <http:// www.springerlink.com/content/1385-0237/213>. Acesso em: 05 maio, 2010. doi: 10.1023 .

VAN DEN BERG, E.; SANTOS, F.A.M. Aspectos da variação ambiental em uma floresta de galeria em Itutinga, MG, Brasil. Ciência Florestal, Santa Maria, v.13, n.2, p.83-98, 2003.

VAN DEN BERG, E.; OLIVIRA-FILHO, A.T. Composição florística e estrutura fitossociológica de uma floresta ripária em Itubutinga, MG e comparação com outras áreas. Revista Brasileira Botânica, São Paulo, v.23, n.3, p.231-253, 2000. Disponível em: <http://dx.doi.org/10.1590/S0100-84042010000200015>. Acesso em: 20 maio, 2009. doi:10.1590.

VELASCO, G. Del N.; HIGUCHI, N. Estimativa de seqüestro de carbono em mata ciliar: projeto POMAR, São Paulo (SP). Ambiência - Revista do Setor de Ciências Agrárias e Ambientais, Guarapuava, v.5, n.1, p.135-141, 2009.

ZAR, J.H. Biostatistical analysis. 4.ed. New Jersey: Prentice Hall, 1998. 929p. 